\title{
Criança e cinema no exercício estético da amizade
}

\author{
Fabiana de Amorim Marcello *
}

Resumo: Busco, neste trabalho, percorrer os caminhos da amizade entre crianças e adultos em dois filmes: Central do Brasil, de Walter Salles (1998) e A língua das mariposas, de José Luis Cuerda (1999). Inicialmente, retomo algumas discussões acerca da temática da amizade, do caráter ético, político e também de criação que ela comporta, tomando como base os trabalhos de Michel Foucault. Em seguida, analiso os filmes em questão, buscando mostrar o quanto as alianças feitas entre amigos se traduzem, no cinema, em função da potência de uma relação, mas também em torno da possibilidade de a criança fazer-se potente e de potencializar outrem. Busco, portanto, falar da amizade como exercício de autotransformação, como busca e criação de si mesmo - enfim, a partir de práticas que não se fazem na solidão.

Palavras-chave: cinema; criança; amizade.

\section{Children and films in the aesthetic exercise of friendship}

Abstract: In this article I will follow the paths of friendship between children and adults in two films: Central Station, by Walter Salles (1998) and La Lengua de las Mariposas [Butterfly's Tongue], by José Luis Cuerda (1999). First, I will recall some issues about the topic of friendship, as well as its ethical, political and creative character, drawing on Michel Foucault's works. Then, I will analyze both films, seeking to show to what extent bonds between friends are translated, in a filmic way, as a result of the power of a relationship, and also of a child's possibility of empowering himself or herself and others. I thus seek to discuss friendship as an exercise of self-transformation, as a search for and creation of oneself - through practices that cannot be undertaken in solitude.

Key words: cinema; child; friendship.

Não é difícil observar que a amizade é um tema constante no cinema. Nos filmes em que a criança é protagonista, isso fica ainda mais evidente. Uma primeira análise de um conjunto de filmes permite afirmar que há algo "a mais" na relação de parceria, de aliança que as crianças protagonistas dos filmes

\footnotetext{
* Professora do Programa de Pós-Graduação em Educação da Universidade Luterana do Brasil (Ulbra). Membro do Núcleo de Estudos em Mídia, Educação e Subjetividade (Nemes) da Universidade Federal do Rio Grande do Sul (UFRGS), Porto Alegre, RS, Brasil. famarcello@uol.com.br
} 
estabelecem com outros personagens, e mesmo entre si. Há, talvez, algo "a mais" que provém, que escapa da relação que as crianças estabelecem com seus pares e que, entendo, merece ser ressaltado na medida em que, nada melancólico ou óbvio, diz respeito à constituição genuína da sensibilidade estética.

Algo "a mais" se passa no desejo nutrido pelos pequenos engraxates Giuseppe e Pasquale de comprar um cavalo branco, em Vitimas da tormenta - mesmo que esse desejo seja, mais tarde, cercado pelo desespero de estarem confinados em um reformatório (De Sica, 1946). Mesmo quando não falamos da relação entre crianças, mas de outros laços que elas acabam por estabelecer em tantos filmes, há algo que não se deixa apreender de imediato: falamos, portanto, de algo mais amplo: de relações que vão além daquelas óbvias que poderiam ser estabelecidas, por exemplo, entre adultos e crianças e que, por isso mesmo, passam a ser de outra ordem. Nesse caso, podemos lembrar a amizade totalmente dissociada de noçôes paternalistas ou superprotetoras: "mais que um pai, Carlitos é o irmão d'O garoto" (Vallet, 1991, p. 21, tradução minha); na relação entre o menino Marcelino e Jesus, em Marcelino, pão e vinho (Vajda, 1954), contemplamos a relação inefável que se inicia com o gesto espontâneo e singelo do menino que, ao olhar para o rosto de dor e sofrimento de Cristo talhado na madeira, diz: "Tens cara de quem está com fome". Essas relações que afirmo ser "de outra ordem" poderiam, ainda, estar relacionadas à fidelidade, à lealdade da amizade ou do abrigo que ela, na verdade, representa, por exemplo, no caso de Totó a Savatore, em Cinema Paradiso - sentimentos que se estabeleciam ali, dentro do cinema, na pequena Giancaldo, mas que o extrapolaram e transformaram-se em marcas de vida, tanto de um, como do outro.

Enfim, seria possível listar muitos filmes e incontáveis relações entre crianças e mesmo entre adultos e crianças que nos inspiram a pensar o conceito de amizade de uma outra forma. Observo que essas relações permitem, do mesmo modo, pensar o conceito de criança diferentemente daquele que remete a criança a um ser aprendiz, um ser domado e sempre previsível.

Assim, busco, neste trabalho ${ }^{1}$, percorrer os caminhos da amizade, em especial, em dois filmes: Central do Brasil, de Walter Salles e A lingua das mariposas, de José Luis Cuerda. Primeiramente, retomo algumas discussóes acerca da temática da amizade, do caráter ético, político, e também de criação que ela comporta no âmbito da filosofia - tomando como base os trabalhos de Michel

1. A pesquisa da qual este texto é resultado contou com o apoio financeiro do CNPq (Bolsa de Doutorado) e da Capes (Bolsa de Estágio de Doutorado no Exterior). Com algumas modificações, trata-se do trabalho aceito para ser apresentado na $\left.3\right|^{\text {a }}$ Reunião Anual da Associação Nacional de Pós-Graduação e Pesquisa em Educação (ANPEd), no GT de Educação e Comunicação (Caxambu, 2008). 
Foucault sobre a temática. Em seguida, analiso os filmes em questão, buscando mostrar o quanto as alianças feitas entre amigos se traduzem, no cinema, em função da potência de uma relação, mas também em torno da possibilidade de a criança fazer-se potente e de potencializar outrem. Busco, portanto, falar da amizade como exercício de autotransformação, como busca e criação de si mesmo - enfim, práticas que não se fazem na solidão.

\section{Amizade e novas formas de pensar os relacionamentos}

Numa das últimas entrevistas concedidas por Michel Foucault, o filósofo afirmava, categoricamente: "Se há alguma coisa que me interessa hoje, é o problema da amizade.” (Foucault, 1994b, p. 744, tradução minha). Apesar disso, o tema da amizade não pôde ser amplamente desenvolvido por Foucault por conta de sua morte prematura. É a partir do último curso ministrado por Foucault no Collège de France, intitulado $A$ hermenêutica do sujeito e das entrevistas que ele freqüentemente concedia aos mais variados meios de comunicação que podemos reunir algumas conclusões em relação a esse que certamente viria a ser alvo de um trabalho de pesquisa por parte do filósofo: "depois de ter estudado a história da sexualidade, creio que deveria tentar compreender a história da amizade, ou das amizades." (Foucault, 1994b, p. 744, tradução minha).

Se o tema da amizade nos interessa aqui é porque ele fornece elementos para pensar a criança no cinema. Tal como entendida por Foucault, a amizade não teria como objetivo a fixidez de identidades ou mesmo a institucionalização das relações, mas sua imediata subversão (tanto das identidades fixas, quanto das relações institucionalizadas). Nessa perspectiva, a amizade concentra um mundo de possibilidades: no jogo com o amigo, torna-se possível para o indivíduo um movimento de autotransformação, jamais previsto de antemão, jamais entendido como resultado ou como objetivo último e, sim, como espaço de afirmação e, sobretudo, de criação.

É preciso situar no âmbito de que discussão o tema da amizade insere-se na obra de Foucault. A amizade aparece, especialmente, na última fase de trabalho da vida do autor, quando ele mergulha nos textos da Antigüidade grecoromana para examinar a produção ética e estética de si mesmo. A atenção do filósofo sobre a ética distancia-se das noções mais comuns sobre a moral e centra-se, sobremaneira, nas formas pelas quais o sujeito se transforma e estiliza sua própria existência. Assim como todo o percurso teórico e existencial de Foucault, o estudo desses textos não estava afastado de suas indagações sobre seu tempo: ele dizia respeito à possibilidade de pensarmos uma ética do presente (Loponte, 2005, p. 74). 
Como mostra o filósofo francês, o exercício da amizade para os gregos não estava separado de um exercício de ascese, ou seja, de um trabalho exercido pelo indivíduo sobre si mesmo; ascese entendida, ainda, como "atividade de autotransformação" (Foucault, 1994c; Ortega, 1999, p. 57). Importa destacar, desde já, que o si mesmo e o eu sobre os quais falamos aqui não são entendidos numa dimensão psicológica: "essa interioridade não tem a forma de um sujeito, de um eu, mas de um si mesmo, correspondente à categoria de indivíduo." (Ortega, 1999, p. 72). Tais assimilações eram desconhecidas para os gregos, e não é, portanto, em torno de uma psicologização que se alicerçam as análises foucaultianas.

O trabalho do indivíduo sobre si mesmo - do qual a amizade fazia parte - não estava somente limitado ao domínio estético (da existência), mas também, e talvez, sobretudo, ao (inseparável) domínio ontológico: "por meio dele alcança-se uma transformação total da forma de pensar e ser, a metamorfose do eu, a superação da própria individualidade e de seus limites." (Ortega, 1999, p. 53). A amizade implicaria, então, uma junção aparentemente paradoxal entre um conjunto de práticas de si na Antigüidade: o cuidado de si e o desprender-se de si.

É o fato de estar ligada a um "desprender-se de si mesmo" que permite à amizade formas de criação e não de previsão ou de antecipação do que ainda está por vir. Em relação ao trabalho do intelectual hoje, Foucault mostra-nos o que seria esse "desprender-se de si mesmo": diferente de desenvolver um campo de conhecimento factível ou de proceder em direção a uma recusa de si, desprender-se de si mesmo significa deixar-se levar por aquilo que não é auspiciado ou esperado. Trata-se, portanto, da capacidade do indivíduo de "modificar não somente o pensamento dos outros, mas também o seu próprio pensamento." (Foucault, 2004b, p. 248).

Paralelo a isso, o cuidado de si não se apresenta como prática egocêntrica, egoísta ou individualista. Ao contrário, o cuidado de si pode ser entendido, a um só tempo, como relação consigo mesmo e como "movimento de si para o outro" (Ortega, 1999, p. 129); cuidado de si também, portanto, como cuidado dos outros. É o papel do outro que se estabelece como essencial tanto para a autoconstituição, como para a autotransformação. $\mathrm{O}$ indivíduo torna-se sujeito também com o outro, na relação que estabelece com o outro. Na Antigüidade greco-romana, isso significava uma constituição estética de si, por meio da relação com a figura do mestre, do professor e, igualmente, a do amigo (Foucault, 2004b).

Vale destacar, no que concerne às comparações que podemos fazer com a era moderna, que o que tem primazia nas relaçōes intersubjetivas greco-romanas é o cuidado de si e não o conhecimento de si. A diferença entre as duas práticas é radical: "na cultura greco-romana, o conhecimento de si aparece como conse- 
qüência do cuidado de si. No mundo moderno, o conhecimento de si constitui seu princípio fundamental." (Foucault, 1994a, p. 789, grifo meu). O que muda é que, como modo de ser, o conhecimento de si é "inteiramente definido pelo conhecimento" e, com isso, "submetido ao ideal de um fundamento da cientificidade" (Foucault, 2004b, p. 279-289).

Ainda em relação à amizade, pode-se dizer que ela não seria simplesmente um lócus de consenso, de placidez ou de tranqüilidade. Antes, ela é o lócus nos quais são travadas lutas de força: "no amigo, não devemos procurar uma adesão incondicional, mas uma incitação, um desafio para nos transformarmos." (Foucault, 2000, p. 80). A amizade é, assim, também o espaço vazio, ainda por se fazer, no qual exatamente por isso os indivíduos devem ser capazes de viver em suas contradições e tensões, um lugar no qual fosse possível um "determinado agonismo e que não pretendesse anular as diferenças" (Foucault, 2000, p. 80).

O que faz com que algo seja considerado agonístico é o fato de aumentar ou "revigorar" a atividade (em oposição à noção de passividade). Se isso acontece, pode-se dizer que a relação, qualquer que seja ela, dá-se "verdadeiramente"; ou, de forma equivalente, se nos relacionamos com algo "verdadeiramente" é porque esse algo aumenta ou revigora nossa capacidade de ação; portanto, "age como um agonista convencional sobre nós." (Matilla, 1999, p. 2, tradução minha). Tal como explicado por Miguel Matilla, "tanto o adjetivo 'agonístico' - no sentido figurado de relativo a ou agindo como um agonista sobre nós -, como o substantivo agonista significam 'tudo aquilo que aumenta nossa atividade" (Matilla, 1999, p. 2, tradução minha).

O que importa sublinhar é que todo processo de cuidado de si e cuidado dos outros não está separado de uma prática de preparação, da organização de um "equipamento" para os acontecimentos da vida (Foucault, 2004a, p. 387395). Uma preparação que é, por certo, aberta e suscetível a variações e transformaçōes. Trata-se, assim, da possibilidade de aparelharmo-nos para o futuro, para aquilo que está por vir e que, de fato, desconhecemos. Ou seja, trata-se aqui da amizade como elemento potencialmente útil para nos fornecer bases sobre as quais possamos ser "mais fortes do que tudo que possa acontecer ao longo de nossa existência" (Foucault, 2004a, p. 388).

Partindo do conceito de amizade tal como desenvolvido por Foucault, passo agora à análise dos filmes propriamente dita. Interessa-me aqui mostrar como se tecem as redes de amizade, especialmente em dois materiais: A língua das mariposas e Central do Brasil. Meu objetivo, então, é descrever, por um lado, como Don Gregório invade a vida do menino Moncho, transformando-a e sendo transformado e, por outro, como Josué se relaciona com Dora e, no jogo da amizade, como ambos se superam a si mesmos. 


\section{A língua das mariposas e a amizade para além do salvacionismo}

A lingua das mariposas é baseado em três contos do autor espanhol Manuel Rivas: La lengua de las mariposas, Carmiña e Un saxo en la niebla. O filme tem como tema central a relação de amizade estabelecida entre o velho professor Don Gregório e o menino Moncho, de sete anos. Enquanto o primeiro está prestes a se aposentar, o segundo recém inicia sua vida escolar. A amizade entre os dois estabelece-se justamente nesse espaço entre a retirada de um e a entrada do outro na cena pedagógica stricto sensu. Vemos, porém, que se trata de uma relação não circunscrita às paredes da sala de aula, mas que asatravessa, mobilizando tanto o professor quanto o aluno a uma série de trocas para além dos conteúdos disciplinares. A relação entre Don Gregório e Moncho é invadida de forma intensa pelos prenúncios da Guerra Civil Espanhola (1936-1939) e a ascensão do regime ditatorial franquista. Don Gregório, assim como o pai do menino e outros habitantes do pequeno vilarejo espanhol dentro do qual a narrativa se dá, era uma das figuras de resistência ao modelo de governo que logo se tornaria vigente.

De início, seria importante perguntar qual a diferença entre a relação de amizade aqui desenvolvida entre professor e aluno e aquelas já tão tradicionais, presentes em tantos filmes, tais com como $A$ sociedade dos poetas mortos, de Peter Weir (1989); Conrack, de Martin Ritt (1974); Meu mestre, minha vida, de John Advilsen (1989); Ao mestre com carinho, de James Clavell (1967); etc.

Primeiramente, cabe dizer que não se trata aqui da apresentação de uma "pedagogia do herói" (Fabris, 2001), comum em filmes hollywoodianos, cujos personagens centrais são professores, alunos e escola. Não vemos uma escola degradada, alunos perdidos e um professor que irrompe nesse espaço a fim de transformá-lo radicalmente. Não é a figura do professor-cometa, que surge iluminando o conjunto de ações escolares - mesmo que isso, ao final do filme, acabe geralmente conduzindo à sua demissão. Antes, a relação professor-aluno em $A$ lingua das mariposas é suspensa, e o que toma a cena é somente aquilo que escapa às relações institucionalizadas.

Nas narrativas hollywoodianas,

esses professores, na maioria homens, são posicionados em histórias, nas quais brilham em confronto com a escuridão das escolas que são projetadas nas telas do cinema ou das televisões. As escolas são representadas como locais de não-saber (conhecimentos) e de não-ser (educado), onde se travam conflitos dos mais variados, desde tráfico de drogas, gravidez precoce até violências, etc. É um reduto da violência urbana, mas, ao mesmo tempo, é essa escola que na figura de um professor herói, 
milagreiro e santo, pode transformar a situação. Mas todos os problemas se resolvem graças ao professor herói (Fabris, 2001, p. 6-7).

Assim, observamos que o movimento de transformação ou mesmo da permeabilidade da presença de Don Gregório em Mocho não se dá como um gesto de alteração de estados: de um menino ingênuo, oprimido, para outro liberto e mais lúcido. Não se trata de um progresso, nem de um desenvolvimento em termos de maturidade. Diferentemente dos filmes que citei, em $A$ lingua das mariposas, a posição do professor, e especialmente da amizade que ultrapassa a relação institucional, não é figura de onde provém uma iluminação instantânea ou aquela que, de um momento a outro, faz com que o outro "abra os olhos" (Foucault, 2004b, p. 248). Ao invés desse movimento, trata-se da proposição de um outro exercício sobre si mesmo, só possível dentro de uma relação sem finalidade; um exercício, portanto, no qual a única maturidade que está em jogo é a do olhar e do gesto: a delicadeza do convite ao olhar aguçado para a asa de uma borboleta ou para a língua de uma mariposa, ao despertar da sensibilidade de ouvir o grilo-rei cantar no meio do mato; ou do aceno à curiosidade, radicado na singela afirmação de que algumas aranhas inventaram, há milhares de anos atrás, o submarino.

O cinema não é apenas a escritura do movimento, mas a escritura do gesto (Larrosa, 2006), a partir da conversão do olhar. É justamente o ato de inscrever a amizade entre professor e aluno no espaço da conversão do olhar que diferencia este filme dos que citei acima - e talvez o aproxime de outros, como Cuore, lembranças do coração, de Luigi Comencini (1986) ou Crainquebille, de Jacques Feyder (1922). O que essa amizade propõe é um movimento de transformação lenta e gradual, que nada tem a ver com salvacionismo. A amizade, nas descrições dadas por Foucault, não supõe o domínio de um, do alto de um saber, em relação a outro, ainda em estado imaturo - embora se dê "na figura do mestre, guia, professor, amigo.” (Ortega, 1999, p. 133). A conversão do olhar difere do exercício de conscientizar, como tradicionalmente entendido, pois o primeiro não diz respeito a uma conduta com um fim específico e nem é o caminhar de um lugar para o outro: o gesto ou a conversão do olhar é o fim em si mesmo, ele é, em si mesmo, movimento. Na qualidade de gesto, o que importa não é a transcendência, mas a imanência que se coloca exterior a relações de oposição (melhor versus pior, bem versus mal, verdadeiro versus falso).

Tal como referido, a relação de amizade não supõe idéias de um democratismo abstrato e quimérico da igualdade entre um e outro. Da mesma forma, seria ingênuo afirmar também que não existe nenhuma relação de superioridade entre Don Gregório e Moncho ou que o adulto esteja absolutamente livre da tarefa de ensinar coisas à criança. No entanto, há uma relação de respeito e de 
dignidade que merece ser ressaltada. Nervoso com seu primeiro dia de aula, Moncho acaba fazendo xixi nas calças em frente aos colegas de sala, enquanto o professor pede que ele diga seu nome em voz alta. Frente à reação das crianças, que riem, Moncho corre e foge da sala de aula. Horas depois, Don Gregório vai à casa de Moncho para falar com seus pais, para saber como ele está, mas, acima de tudo, para desculpar-se com o menino: "Ele é um garoto muito sensivel, gostaria de pedir-lhe perdão e, além disso, pedir-lhe para voltar para a escola". Os pais insistem em agradar o professor, oferecendo-lhe petiscos e dizendo que não há nada do que se desculpar. O professor, no entanto, pede que a mãe vá chamá-lo. O diálogo entre os pais e o professor é acompanhado de longe, às escondidas, por Moncho. Não somos apresentados à cena "oficial" do pedido de desculpas, mas diretamente convidados a acompanhar a seqüência que mostra o dia seguinte, já na escola, quando Don Gregório chega à sala de aula, segurando Moncho pela mão. O professor apresenta o "novo" aluno aos demais e pede que os colegas o recebam com uma salva de palmas. E é ao seu lado que, naquele dia, Moncho assiste à aula.

Um novo mundo apresenta-se ali, a partir da entrada da escola e, especialmente, de Don Gregório em sua vida. Ensinamentos que ganham ares de grandes descobertas, ao mesmo tempo que não se parecem com aqueles da sisudez de um organograma curricular tradicional: na conversa com a mãe e com o irmão adolescente, à noite, na cozinha, Moncho pergunta: "sabem de onde vêm as batatas? Elas vêm da América. Não existiam aqui". A mãe, desconfiada, questiona: "Não diga bobagens. E o que as pessoas comiam, então?". Moncho responde: "Castanhas. Antes de Colombo não havia batatas na Espanha". Ou quando Moncho pergunta ao irmão: "Você sabe onde fica a Austrália?". O irmão responde: "Na América?". E Moncho corrige: "Na Oceania. E você sabe o que é um 'tilonorrinco?? É um pássaro que mora na Austrália. Quando está apaixonado, dá uma orquidea para a fêmea. Uma flor muito bonita, que custa muito dinheiro".

Esse novo mundo transforma a criança não para uma conversão - no sentido cristão, de uma "súbita mutação", uma ruptura radical, na qual "o eu que se converte é um eu que renunciou a si mesmo" (Foucault, 2004a, p. 259-260, grifos meus), mas para a abertura de novas possibilidades; transforma o indivíduo não no sentido de uma falência ou morte do indivíduo anterior, mas em torno da descoberta de que outros mundos são possíveis. Se há uma ruptura aqui em questão, ela diz respeito, sobretudo, não ao indivíduo em relação a si mesmo, mas àquilo que o cerca (Foucault, 2004a, p. 259-260). Durante uma conversa com Don Gregório, o padre do vilarejo chama Moncho. Se os dois adultos aparecem no tradicional plano-americano, Moncho, como em grande parte das vezes, é mostrado praticamente em close. O padre, então, aplica-lhe um pequeno "teste oral" em latim, uma espécie de tradicional jogral, daqueles 
freqüentemente vistos em missas. $\mathrm{O}$ menino, porém, esquece a última parte. Era exatamente isso que o padre queria mostrar a Don Gregório: "Está vendo? Ele não lembra". Don Gregório apenas sorri e diz: "Não sabia que ele ia ser coroinha". O padre, irônico, explica: "Exatamente: 'ia'. Você disse tudo. Logo que começou a freqüentar a escola, começou a perder o interesse pela igreja". A partir disso, padre e professor estabelecem uma discussão com base de diálogos em latim: "Nidos tepentes absilunt aves. Aves deixam seu calor nos ninhos", diz o padre. Ao que Don Gregório responde: "Libertas virorum fortium pectora acuit. A liberdade estimula o espirito dos homens fortes". Fugindo de um possível clichê, que reduziria a situação a uma tomada de consciência por parte do garoto em relação aos valores conservadores da igreja, o que vemos aqui é apenas o despertar para novas descobertas. É o ato de poder pensar-se a si mesmo para além dos destinos previstos.

A relação de amizade é o movimento de pensar-se a si mesmo em relação ao outro. É expor-se ao outro, abrindo-se não para uma imediata inteligibilidade, mas para a espessura mínima dos ditos. Como quando Don Gregório confessa para o menino a dor de perder a esposa tão jovem: a morte da esposa que, em seu lugar, deixou "uma cama deserta, um espelho velho e um coração vazio". Ainda assim, pensar o outro é pensar-se no outro. Ao escolher que livro dar para Moncho, Don Gregório hesita, pega um manual comunista como $A$ conquista do pão, de Kropotkine, e acaba dando $A$ ilha do tesouro, de R. L. Stevenson. Pensar-se a si mesmo pelo outro expressa-se no filme quando Don Gregório dá ao menino uma rede de caçar borboletas para que, juntos, vão à mata, descobrir mais sobre a língua microscópica das mariposas: "A língua chama-se 'tromba espiral", diz Don Gregório. "E podemos ver?", pergunta Moncho. "Não, agora está enrolada. A língua das mariposas é como uma mola de um relógio. É para alcançar o néctar que as flores possuem no cálice", finaliza o professor.

Ao final do filme, as turbulentas transformaçôes pelas quais o país atravessava colocam Don Gregório numa situação delicada. Ele é preso e agora está prestes a ser levado pelo exército. A cidade inteira acompanha a saída dos "comunistas" de dentro do edifício em direção ao caminhão aberto que os transportaria. Para tanto, os presos devem atravessar um corredor formado pelas pessoas, que encontram nos insultos a forma de distinguir-se daqueles agora perseguidos. A cada pessoa que sai, o olhar de surpresa do menino, que vê ali não o "criminoso", mas apenas o pai de um amigo, acompanhado da dor da família. O último a sair é Don Gregório. Para distanciar-se de qualquer relação com o professor, a mãe pede ao garoto que grite, que o chame de "ateu", de "comunista". O menino atende ao pedido da mãe, grita, mas não faz só isso: corre atrás do caminhão e, com pedras na mão, repete: "ateu!", "comunista!", somados a enigmáticos "tilonorrinco!", "tromba espiral!". 
Podíamos resumir a seqüência afirmando que se trata da destruição das relações afetivas provocadas pelo fascismo. Ou, quem sabe, o contrário: dizer que nem a ditadura mais voraz pode apagar as marcas da amizade. Moncho estaria passando uma espécie de recado secreto ao professor, ao mostrar que sempre lembraria de suas liçōes? Ou o menino apenas se volta contra Don Gregório, usando justamente o que ele lhe havia ensinado? A lágrima que corre em seu rosto, a expressão em close entre um rosto expressivo e um punho fechado com uma pedra na mão é de tristeza? De raiva? O final não se perde no melodrama, nem na obviedade de mostrar a reação de decepção e tristeza ou de uma relativa alegria do professor frente à atitude do menino - imagem que talvez fosse nos fornecer indícios que, então, revelassem-nos o sentido derrisório daquele gesto. Não vemos a reação do professor, mas tão-somente o rosto congelado do menino e que, pouco a pouco, perde as cores e torna-se imagem fixa em preto-e-branco. Mais do que explicações para a seqüência final, o que se abre para nós é a imagem da criança na sua mais genuína imprevisibilidade, sua presença enigmática, recusando qualquer explicação linear ou fatalista. É ali, exatamente ali, que a criança nos tira a voz e as certezas. É ali, exatamente ali, que se faz potência em nós, por introduzir o elemento da dúvida. Trata-se, portanto, do espaço aberto ou, mesmo, do vazio que é instaurado no interior da incerteza. E é ali, exatamente ali, que a criança nos escapa.

\section{Central do Brasil e a amizade como metáfora da viagem}

Um dos filmes nacionais que obteve mais sucesso mundialmente, Central do Brasil, de Walter Salles, apresenta-nos a relação turbulenta entre Josué e Dora. Dora é a professora aposentada que, para complementar as despesas domésticas, escreve cartas para analfabetos na estação ferroviária que dá nome ao filme, no Rio de Janeiro. Uma das clientes de Dora é Ana, que vai até ela a pedido do filho, Josué, para escrever uma carta ao ex-marido, o pai que Josué nunca conheceu. As cenas iniciais do filme mostram as agruras de uma sociedade analfabeta; num mar de rostos em close: olhando diretamente para nós, lugares e cidades de um país tão vasto e, ao mesmo tempo, tão desconhecido: Mimoso, Pernambuco; Cansanção, Bahia; Carangola, Minhas Gerais; Relutaba, Ceará; Muzambinho, Minas Gerais.

Dora, no entanto, é também a juíza, que, ao lado de sua amiga Irene, decide quais cartas "merecem" ser postadas ou não. Quando não são rasgadas imediatamente, seguem para um "limbo": uma gaveta no armário, à espera de serem ou não enviadas a seus destinatários. No dia seguinte, Ana vai novamente até Dora pedir-lhe para revisar a carta que escrevera no dia interior. Pede, além disso, que inclua uma foto do menino. Minutos depois, ao atravessar a 
rua, Ana é atropelada por um ônibus e morre ali mesmo, em frente ao filho. Josué agora perambula sozinho pelos corredores da Central do Brasil - a imensa e escura estação durante a noite, vazia; mas também pequena, tumultuada, nem por isso menos sombria, entre trens e lanchonetes, policiais, vendedores e passantes durante o dia.

Vendo Josué sozinho, Dora encontra ali a possibilidade de ganhar um dinheiro extra: vender o menino para uma quadrilha de roubo de órgãos. Dora entrega o menino, com a promessa de que iriam cuidar bem dele. Volta para a casa, compra uma televisão nova, mas não consegue dormir. Sabe que há um limite de si mesma que foi ultrapassado. No dia seguinte, ela retorna ao apartamento da quadrilha e tira o menino de lá, ao mesmo tempo que se vê obrigada a fugir do Rio de Janeiro para não ser talvez morta. É então que, junto com Josué, Dora parte para Bom Jesus à procura do pai desconhecido, tendo em mãos apenas a carta deixada por Ana.

Neste momento, começa a viagem de Dora e Josué. Mais do que buscar uma cidade, do que desbravar terras virgens, do que a certeza do destino final, os dois são lançados para a viagem como metáfora, como possibilidade de efetuar uma travessia da qual não se sai idêntico. "Viajar é isto: deslocar-se para um lugar onde possamos descobrir que há, em nós, algo que não conhecíamos até então." (Calligaris, 2007, p. 1). A viagem aqui, vivida ou metafórica, é marcada pelas tensões, pelas transformaçôes, pelos encontros e desencontros, por aquilo que se ganha e por aquilo que se vai perdendo pelo caminho.

No meio da viagem, ambos vão deixando e perdendo um pouco de si mesmos: o apartamento fica abandonado e a vida no Rio de Janeiro, suspensa; a mochila dentro do ônibus e o dinheiro dentro da carteira são perdidos. Apesar disso, Dora e Josué agarram-se às únicas certezas que têm: o menino, que "pôs na idéia" de querer conhecer o pai, insiste em ter nas mãos o único objeto-carta que liga, a um só tempo, o pai que nunca viu e a mãe que recém morreu; Dora, sisuda, vestindo calças e roupas austeras, sem maquilagem e com o rosto já cansado da jornada que mal começou, agarra-se ao mínimo de controle que pensa poder ter sobre a situação: "a gente devia andar só de ônibus, nunca de táxi. O ônibus tem o caminho certo, tem o lugar certo, já o táxi não, ele toma um rumo qualquer e depois se perde".

No início, os corpos pouco se tocam, pois são apartados pelo encosto de braço do ônibus e pela distância que, resistentes, preferem manter um do outro. Quando Dora encosta em Josué, é para agarrar-lhe o braço com força. Os dois marcam suas diferenças a partir de posicionamentos irrisórios: "Nunca se esqueça de roubar mortadela", diz Dora. "Eu detesto mortadela!", responde Josué. "Mentirosa" é nome que Josué dá àquela mulher, enfrentando de frente o cinis- 
mo, a hipocrisia, a aridez daquela que em nada se assemelha à sua mãe. "Moleque" é o nome que Dora dá ao menino, como se expressasse ali a tentativa de impor um respeito que não existe e de diminuir aquele que, diferente das evidências, obrigou-a a pegar um táxi e tomar um rumo inesperado e incerto.

Aos poucos, os dois acabam por reconhecer-se em meio à desilusão da vida e do sofrimento, em meio à vegetação agreste, à areia vermelha que marca suas roupas e ao sol intenso que imprime em seus corpos e na imagem uma luminosidade dolorosa. Aos poucos, Josué vai ao encontro de Dora, aproximase dela, senta ao seu lado. Juntos, ao pé de uma imensa rocha sólida, mas sozinhos, de frente para uma chapada infinita, eles ficam em silêncio. Josué apenas pergunta a Dora onde a mãe dele estaria agora. A mão de Dora, neste momento, não pega mais o braço de Josué, mas o pulso, sua mão, ajuda-o a levantar-se para que, juntos, possam colocar o lenço perdido da mãe em um pequeno santuário, daqueles perdidos na beira da estrada.

Os ditos de Josué ecoam de algum modo em Dora: "Você é feia e mentirosa. Por isso que ninguém casa com você. Parece homem, nem tem pintura na cara". Um dos encontros fortuitos da viagem é com o caminhoneiro César. Dora vê ali a possibilidade de, talvez, encontrar um companheiro. Solitário, a estrada e o caminhão de César são os únicos veículos de seu caminhar. Solitária, a rotina e a estabilidade de Dora são os únicos passos que ela almeja para o seu fixar. Dora e Josué pegam carona com César. Aos poucos, os três vão se conhecendo. $\mathrm{Na}$ última seqüência do encontro entre os três, Dora pede licença da mesa do restaurante em que vão almoçar e vai até o banheiro. Olha-se no espelho, analisa-se, tenta arrumar os cabelos. Ao ver ali uma outra mulher, pede-lhe emprestado o batom; ela quer agora "colocar pintura na cara". O que fala ali é a voz da vaidade (ou seriam apenas os ecos de Josué?), mas, acima de tudo, tratase do exercício de expor-se ao outro, mesmo que, depois, este venha a rejeitá-la.

O que antes afastava Dora e Josué, agora os torna próximos; o que antes os fazia culpados da desgraça mútua, faz-se agora elemento de cumplicidade. A falta de dinheiro e a decepção de estarem perdidos (por mais que já estivessem na cidade destino, Bom Jesus do Norte) acabam tornando-se estopim para mais uma discussão. Numa das seqüências mais belas do filme, Josué foge de Dora, cruzando um mar de pessoas que, à noite, estão em procissão; cada qual com uma vela na mão. No meio da escuridão, da multidão e das orações dos crentes, ouvimos os gritos de Dora, desesperada, ritmados pelos sons dos passos rápidos de Josué, que foge. Por alguns minutos, Dora perde-se de Josué. Hipnotizada pelos cânticos, pela fumaça das velas e pela luz avermelhada da película, ela desmaia. Quando acorda, não vê mais nem crentes, nem velas, nem santos, mas tão-somente o rosto sorridente do menino, as pernas pequenas, nas quais agora ela pode repousar sua cabeça cansada. 
É a partir desse momento do filme que, sem nenhum "acerto de contas" explícito, os dois retornam ao começo, porém transformados: famintos e precisando de dinheiro, Dora volta a escrever cartas, mas, agora, numa mesa improvisada e tendo um ajudante. Cartas que agora não vão mais para uma gaveta, mas para o destino indicado pelo remetente. É nesse espaço de amizade que ambos se transformam naquilo que são. É neste espaço que "moleque" e "mentirosa" passam a ser, um para outro, apenas e finalmente "Dora" e "Josué".

A relação de amizade agora firmada implica também outras incertezas, implica lidar com outras contingências dispostas pelo caminho. Referindo-se à memória do pai, Josué diz a Dora, já quase no final da travessia: "Tem hora que eu lembro, tem hora que ele se desmancha na minha cabeça. Eu não quero esquecer de você”. São essas as dúvidas que agora pairam em Dora, já que, uma vez restituído à família que pertence, Josué seguirá um outro caminho. Dora sai da vida de Josué com o vestido azul e floreado que ganhou do menino, mas, acima de tudo, ela sai de sua vida não como uma mulher "boazinha", mas como alguém "mais forte". É ela agora quem escreve uma carta, desocupando, assim, o espaço no qual ela até então sabia se movimentar: o de "juíza" dos ditos alheios. É ela agora quem aposta na confiança e na coragem ao escrever/ dizer, emocionada, para o menino: "tenho medo de que você me esqueça". O olhar antes divergente agora converge para uma mesma imagem: em planos distintos, vemos Dora e Josué olharem, ao mesmo tempo, a foto que tiraram juntos no dia da procissão, ou seja, no dia em que se perderam, mas que, paradoxalmente, também se encontraram.

O que observamos, assim, é que Dora e Josué, agora separados, tornam possível - um em relação ao outro, um em função do outro - a vivacidade da "superação de si" (Foucault, 2004a, p. 388). Uma superação de si que não tem a ver com sentidos de simplesmente ser "melhor" do que antes, ou de, a partir de então, poder ultrapassar os outros. Não se trata de desenvolvimento, nem de gradação; não se trata de prevalecer sobre os outros, nem de triunfar entre os seus. Superação de si como capacidade de "ser mais forte" ou, talvez, mais modestamente, "de não ser mais fraco do que aquilo que pode acontecer." (Foucault, 2004a, p. 388).

\section{Considerações finais}

Busquei, neste trabalho, analisar os filmes $A$ lingua das mariposas e Central do Brasil, tendo como mote a discussão acerca das relações de amizade estabelecidas entre adultos e crianças. Para sustentar tais análises, fiz uso dos estudos de Foucault sobre a temática da amizade, entendendo tal conceito a partir de uma ótica que o considera como "forma de vida" (Ortega, 1999, p. 
158). A importância do tema para o autor estava radicada nas possibilidades de abertura que esta forma de vida podia encarnar: não "a" verdadeira amizade, a "boa" amizade no sentido daquela que aspira ao consenso. Ao contrário, trata-se aqui de múltiplas formas de reinventar relaçôes que ainda não estariam tomadas e inteiramente permeadas por sentidos e controles institucionais. Assim, ao invés de resumirmos as discussões, lançando-as para um rol de "exemplos" de amizade - passíveis ou não de serem repetidos -, o que os filmes nos mostram são apenas algumas das inúmeras formas que a amizade pode encarnar. Não se trata aqui de moldes, assim como para Foucault nunca foi objetivo fazer dos gregos um exemplo a ser rigorosamente seguido - fato discutido por tantos autores (Ortega, 1999; Costa, 1999; Fischer, 2006; Loponte, 2005, etc.). O que o autor propunha, ao contrário, era uma possível atualização da estilização da existência sob novas formas de experienciar a amizade.

A amizade, neste sentido, foi abordada aqui por dois motivos: primeiro, e especialmente, para entendê-la como espaço no qual sobressai a criança como criação, a criança como aquela que se afirma a si mesma na sustentação de sua diferença; a criança que transforma e é transformada no exercício estético da amizade. Em segundo lugar, tal questão foi abordada no intuito de relançar a própria noção de criança para além dos espaços familiares ou das relações de fraternidade humanitárias, que não deixam de ser discriminatórias (Ortega, 2000). Ao fazer isso, ao colocar a criança em primeiro plano nas relaçôes de amizade, estamos a um só tempo redimensionando as potencialidades da criança e lançando a amizade para além das relações privadas e intimistas. $\mathrm{O}$ objetivo, então, foi o de discutir a amizade no âmbito das intersubjetivações ou das "subjetivações coletivas", universos aos quais a amizade pertence (Ortega, 1999, p. 171). Amizade e criança, assim, fortalecem-se no espaço do social e são erigidas à categoria de fenômenos públicos. Pensar o conceito da amizade hoje, como um desafio lançado por Foucault, significa apostar numa espécie de reversão ao nosso "apego exacerbado à interioridade, à 'tirania da intimidade" - processos que não nos permitem desenvolver "o cultivo de uma distância necessária para a amizade.” (Ortega, 2002, p. 161-162). Antes disso, o espaço da amizade é aquele do mundo compartilhado; espaço que é também "da liberdade e do risco." (Ortega, 2002, p. 161-162).

\section{Referências bibliográficas}

CALLIGARIS, Contardo. Folha de S. Paulo, São Paulo, 29 de novembro de 2007, Caderno Mais! p. 1. Texto disponível em: http://www1.folha.uol.com.br/fsp/ilustrad/ fq2911200726.htm. Último acesso: novembro de 2007.

COSTA, Jurandir F. Prefácio. In: ORTEGA, Francisco. Arte e estética da existência em Foucault. Rio de Janeiro: Graal, 1999. 
DELEUZE, Gilles; GUATTARI, Félix. O que é a Filosofia? Rio de Janeiro: Ed. 34, 2000.

FABRIS, Eli H. As marcas culturais da pedagogia do herói. In: REUNIÃO NACIONAL DE PÓS-GRADUAÇÃO E PESQUISA EM EDUCAÇÃO (ANPEd), 24., 2001, Caxambu. Anais... Caxambu, 2001. Texto disponível em http://www.anped.org.br/reunioes/24/ T0859862556596.doc. Último acesso: novembro de 2006. 14 p.

FOUCAULT, Michel. Les techniques de soi. In: FOUCAULT, Michel. Dits et ecrits IV. Paris: Gallimard, 1994a. p. 783-813.

FOUCAULT, Michel. Michel Foucault, une interview: sexe, pouvoir et la politique de l'identité. In: FOUCAULT, Michel.. Dits et ecrits IV. Paris: Gallimard, 1994b. p. 735-746.

FOUCAULT, Michel. À propos de la généalogie de l'éthique: un aperçu du travail en cours. In: FOUCAULT, Michel. Dits et ecrits IV. Paris: Gallimard, 1994c. p. 383-411.

FOUCAULT, Michel. A hermenêutica do sujeito. São Paulo: Martins Fontes, $2004 \mathrm{a}$.

FOUCAULT, Michel. O cuidado com a verdade. In: FOUCAULT, Michel. Ditos e escritos V. Ética, sexualidade e política. Rio de Janeiro: Forense Universitária, 2004b. p. 240-251.

LARROSA, Jorge. As crianças e as fronteiras: várias notas a propósito de três filmes de Angelopoulos e uma coda sobre três filmes iranianos. In: LARROSA, Jorge; TEIXEIRA, Inês de C.; LOPES, José de S. M. A infância vai ao cinema. Belo Horizonte: Autêntica, 2006. p. 51-73.

LOPONTE, Luciana G. Docência artista: artes, estética de si e subjetividades femininas. 2005. 208 p. Tese (Doutorado) — , Programa de Pós-Graduação em Educação, Faculdade de Educação, Universidade Federal do Rio Grande do Sul, Porto Alegre, 2005.

MATILLA, Miguel. An agonistc education: a commentary on the conception of education in Nietzsche's early work. Texto disponível em http://aparterei.com/ap194.htm, 1999. Último acesso: nov. 2003.

ORTEGA, Francisco. Arte e estética da existência em Foucault. Rio de Janeiro: Graal, 1999.

ORTEGA, Francisco. Para uma política da amizade: Arendt, Derrida, Foucault. Rio de Janeiro: Relume Dumará, 2000.

ORTEGA, Francisco. Genealogias da amizade. São Paulo: Iluminuras, 2002.

VALLET, François. L'image de l'enfant au cinéma. Paris: Les Éditions du CERF, 1991.

Filmes citados

A LÍNGUA das mariposas. Direção: José Luis Cuerda. Espanha, 1999. 96 min. Título em espanhol: La lengua de las mariposas.

A SOCIEDADE dos poetas mortos. Direção: Peter Weir. EUA, 1989. 129 min. Título em inglês: Dead poets society.

AO mestre, com carinho. Direção: James Clavell. Reino Unido, 1967. 105 min. Título em inglês: To sir, with love.

CENTRAL do Brasil. Brasil, 1998. $112 \mathrm{~min}$. 
CONRACK. Direção: Martin Ritt. EUA, 1974. 105 min.

CRAINQUEBILLE. Direção: Jacques Feyder. França, 1922. 74 min.

CUORE, lembranças do coração. Direção: Luigi Comencini. Itália, 1984. 115 min. Título em italiano: Cuore.

MARCELINO, pão e vinho. Direção: Ladislao Vajda. Itália/Espanha, $1954.91 \mathrm{~min}$. Título em espanhol: Marcelino, pan y vino.

MEU mestre, minha vida. Direção: John G. Avildsen. EUA, 1989. 109 min. Título em inglês: Lean on me.

VÍTIMAS da tormenta. Direção: Vittorio de Sica. Itália, 1946. 95 min. Título em italiano: Sciuscia.

Recebido em 20 de outubro de 2008 e aprovado em 29 de maio de 2009. 